\title{
Type V Acrocephalosyndactyly
}

National Cancer Institute

\section{Source}

National Cancer Institute. Type V Acrocephalosyndactyly. NCI Thesaurus. Code C99100.

An autosomal dominant inherited type of acrocephalosyndactyly caused by mutations in the FGFR1 or FGFR2 genes. It is characterized by early closure of the sutures between the skull bones, bulging and wide-set eyes, broad thumbs, big toes, and partial syndactyly in the hands and toes. 